\title{
Changes in the microbial communities associated with Gorgonia ventalina during aspergillosis infection
}

\author{
Diego L. Gil-Agudelo ${ }^{1, *}$, Carey Myers ${ }^{2}$, Garriet W. Smith ${ }^{3}$, Kiho Kim² \\ ${ }^{1}$ Instituto de Investigaciones Marinas y Costeras (INVEMAR), PO Box 1016, Cerro Punta de Betín, Santa Marta, Magdalena, \\ Colombia
}

${ }^{2}$ American University, Biology Department, Hurst Hall 105, 4400 Massachusetts Avenue, NW, Washington, DC 20016-8007, USA

${ }^{3}$ University of South Carolina Aiken, Department of Biology and Geology, 471 University Parkway, Aiken, South Carolina 29801, USA

\begin{abstract}
The surface mucopolysaccharide layer (SML) secreted by corals is a rich environment where bacteria live and proliferate, with population levels often being several orders of magnitude higher than in the surrounding waters (at least for culturable microbes). Some studies have suggested that these communities play an important role in energy and nutrient flux in marine environments. We hypothesize that the microbial community structure of the SML also plays a role in protection against disease. This hypothesis is based on studies that have shown differences in the bacterial composition of the mucus of healthy and diseased corals. In this study we tested the differences in the microbial communities living in association with the SML of healthy and diseased Gorgonia ventalina by comparing their metabolic profiles using Biolog EcoPlates. Overall, metabolic profiles of the coral surface microbiota were significantly different to those in the water column based on stepwise canonical discriminant analyses (CDAs). Furthermore, differences between communities living in healthy and diseased corals were also found. Changes were observed between affected and unaffected areas of the same colony, although these changes were not as obvious as between individual healthy and diseased colonies. Results suggest that the microbial communities living in the SML of G. ventalina are affected by the presence of aspergillosis, even if the area is not in direct contact with the infection. This suggests the possibility of changes in the composition of the SML throughout the colony as a response to aspergillosis infection.
\end{abstract}

KEY WORDS: Microbial communities · Aspergillosis $\cdot$ Coral disease $\cdot$ Gorgonia ventalina $\cdot$ Metabolic characterization $\cdot$ Biolog

Resale or republication not permitted without written consent of the publisher

\section{INTRODUCTION}

Corals are covered by mucus that helps in protection against fouling, sedimentation and desiccation (Meikle et al. 1988). This layer is composed, in part, of proteins, mono- and polysaccharides, lipids, and amino acids which produce a nutrient-rich environment where microbes, especially bacteria, can thrive (Ducklow \& Mitchell 1979a,b, Wild et al. 2004a).

Ritchie \& Smith (1995a) found differences between microbial communities living in water and those associated with coral surfaces. Culturable bacterial popula- tions associated with the mucus layer of corals were 2 orders of magnitude higher that those living in surrounding waters, and several orders of magnitude more active metabolically (Ritchie et al. 1996).

Ritchie \& Smith (1995b) compared the metabolic characteristics of bacteria associated with 11 species of corals, and found fewer differences between the more closely related coral species (i.e. those within the same genera) (Ritchie \& Smith 2004), indicating a speciesspecific relationship between corals and their associated bacterial communities. Rohwer et al. (2002), using molecular techniques, found that the association 
between bacteria and corals was not random, and microbial communities showed small differences in the composition of bacterial species in space and time. These differences supported the concept of a 'normal' microbiota associated with coral mucus.

Changes in the normal microbiota of corals were documented by Ritchie \& Smith (1995b), Ritchie et al. (1994), and Jindal et al. (1996) during bleaching events. Also, corals affected by diseases showed changes in microbial composition of the surface mucopolysaccharide layer (SML) (Ritchie \& Smith, 1995a). In other studies, variations in specific components of the normal SML communities were used to detect putative coral pathogens (Patterson et al. 2002, Gil-Agudelo et al. 2004).

The role of the microbial communities on the SML is still largely unknown, although the SML microbiota was shown to have significant importance in the marine food web. Coral mucus can transport energy and nutrients from the reef to the lagoon via the microbial loop, providing a significant energy source to heterotrophic communities (Wild et al. 2004a,b). It is also possible that some of these bacterial communities are consumed by corals, playing a nutritional role for coral polyps by providing nutrients (such as nitrogen) that corals assimilate (Ferrier-Pages et al. 1998). Finally, the normal microbiota might provide protection by occupying niches that otherwise might be inhabited by pathogens, and by producing antimicrobial compounds (Rohwer et al. 2002).

Characterization of the normal microbiota is necessary to understand the causes and consequences of their changes due to diseases. Microbial communities associated with corals are still largely unknown. Rohwer et al. (2002) identified 430 bacterial ribotypes in 14 coral samples by sequencing the 16S rDNA. They suggested that more than 6000 bacterial ribotypes might be present in their samples. Due to the difficulty of characterizing - by either molecular and/or metabolic methods-each of the bacterial types present in the SML of corals, a characterization of the whole microbial community is necessary. Biolog MicroPlates (EcoPlates, Biolog) have been previously used to evaluate microbial communities in soil samples (Winding 1994, Zak et al. 1994, Bossio \& Scow 1995), freshwater (Sinsabaugh \& Foreman 2001) and seawater (Matsui et al. 2001). This method evaluates the functional diversity of the microbiota (PrestonMafham et al. 2002).

In the present study, Biolog EcoPlates were used to compare the microbial communities associated with healthy, diseased, and apparent unaffected areas of diseased sea fan Gorgonia ventalina colonies to assess the differences in their functional diversity and their possible role in coral disease.

\section{MATERIALS AND METHODS}

In August 2002, 2003, and 2004, samples of the SML were collected from healthy colonies of Gorgonia ventalina and from colonies with signs of aspergillosis in Pickles reef $\left(24^{\circ} 59^{\prime} \mathrm{N}, 80^{\circ} 24^{\prime} \mathrm{W}\right)$, Florida Keys. SML samples were vacuumed from the surface of the coral using $10 \mathrm{ml}$ syringes without needles as described by Ritchie \& Smith (1995a). In those colonies affected by aspergillosis, mucus samples were collected from both healthy-looking and diseased portions of the same colony. Water samples were collected for comparison with samples from the SML. Similar samples were collected from $G$. ventalina colonies from Molasses reef $\left(25^{\circ} 01^{\prime} \mathrm{N}, 80^{\circ} 22^{\prime} \mathrm{W}\right)$, Florida Keys, in 2002.

After collection, the samples were transported cold (not frozen) to the laboratory. Once in the laboratory, the samples were inoculated into EcoPlates (Biolog). These plates consist of 96 microwells, containing one of 31 different carbon sources in triplicate (the other 3 microwells do not have any source of carbon and are used as controls). Each microwell also contains tetrazolium violet as an electron acceptor, which indicates dehydrogenase activity and is taken as a measure of general metabolic activity (Ritchie \& Smith 1995b).

Microplates were incubated at room temperature (23 to $25^{\circ} \mathrm{C}$ ). Each plate was read at different time intervals, up to $200 \mathrm{~h}$ after inoculation, using an automated MicroPlate reader (Biolog). Each well was read at 2 different wavelengths: $590 \mathrm{~nm}$ (tetrazolium peak) and $750 \mathrm{~nm}$ (turbidity). For each well, the absorbance of the tetrazolium dye was subtracted from the turbidity absorbance to get the absorbance value that was due to the metabolic activity of bacteria. Values from the control cells were subtracted from values of each microwell to correct for background noise. Average well color development (AWCD) for each substrate $i$ in each plate $j$ at time $t$ was obtained following the formula by Garland \& Mills (1991):

$$
\operatorname{AWCD}(j, t)=\frac{1}{31} \sum_{i=1}^{31} \mathrm{OD}(i, j, t)
$$

where OD is the optical density of the microwell.

The kinetic profile of color development from each bacterial community was determined and the area under the curve was used as a summary statistic to evaluate both maximum color development and rate of color development (Guckert et al. 1996, Haack et al. 1996, Hackett \& Griffiths 1997). The area under the kinetic curve $\left(A_{i k}\right)$ is calculated by combining the OD at consecutive times $(t)$ for each substrate (i) and plate (k) (Guckert et al. 1996, Hackett \& Griffiths 1997):

$$
A_{i k}=\frac{1}{2} \sum_{j=1}^{j=n-1}[t(j+1)-t(j)] \times\left(\mathrm{OD}_{i k t(j+1)}+\mathrm{OD}_{i k t(j)}\right)
$$


The mathematical equivalent of this formula:

$$
\sum_{i=1}^{4} v_{i} t_{i} / 2+\sum_{i=1}^{4} v_{i-1} t_{i} / 2-\sum_{i=1}^{4} v_{i} t_{i-1} / 2-\sum_{i=1}^{4} v_{i-1} t_{i-1} / 2
$$

where $V$ is volume, was used to calculate the area under the curve (Guckert et al. 1996).

Principal component analysis (PCA) has been commonly used to evaluate differences in the functional diversity of samples (e.g. Garland \& Mills 1991, Fritze et al. 1997), but the ratio of number of observations to number of variables suggested by Jackson (1993) would require more than 90 replicates for a 3:1 ratio; there should be at least more replicates than variables (Palojärvi et al. 1997). Instead, a stepwise discriminant function analysis (SDFA) was performed using SAS 8.02 over time during color development in the EcoPlates to detect differences in the metabolic activity among samples. Canonical discriminant analysis (CDA) was performed on the variables selected after the SDFA.

\section{RESULTS}

AWCD from microbial communities from Molasses and Pickles reefs in 2002 did not reach metabolic stability before $72 \mathrm{~h}$ incubation (Fig. 1). In 2003, using longer incubation times, the microbial communities assessed in Pickles reached stability after about $100 \mathrm{~h}$. In 2004, communities showed no signs of stabilization after more than $200 \mathrm{~h}$.

Differences in maximum color development are also shown in Fig. 1. Samples from Pickles 2003 reached stability at an AWCD close to 0.2. Molasses and Pickles 2002 reached similar AWCDs after only 72 h, indicating a higher overall metabolic rate of the microbial communities in these samples. In 2004, samples showed a much lower AWCD, reaching only about 0.15 after more than $200 \mathrm{~h}$ of incubation. The SDFA of the area under the curve of samples from Pickles 2003 showed that activity of seawater microbial communities was lower than of those living on the surface of the corals. Nine carbon sources were responsible for differences when seawater and coral samples were compared: $\beta$-methyl-D-glucoside (A2), ierythritol (C2), Tween 80 (D1), L-threonine (E4), glycogen (F1), glucose-1-phosphate (G2), $\alpha$-ketobutyric acid (G3), $\alpha$-D-lactose (H1), and D-malic acid (H3). Three of these were carbohydrates (A2, C2, and H1), 2 were carboxylic acids (G3 and H3), 2 were poly-

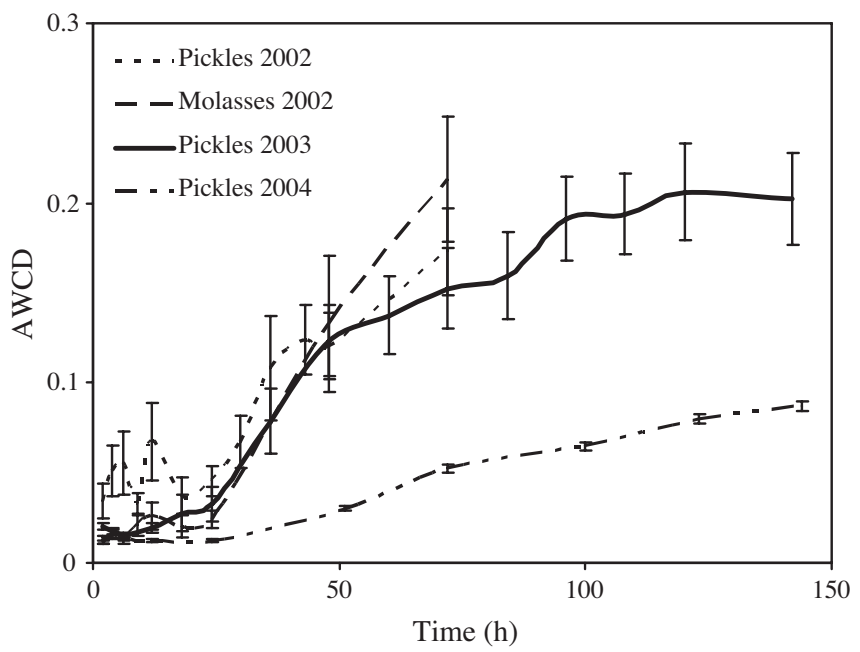

Fig. 1. Average well color development (AWCD) of EcoPlates inoculated with syringe and tissue (only Pickles reef, 2004) samples. Error bars represent $\pm \mathrm{SE}$

mers (D1 and F1), and 1 was an amino acid (E4) (Table 1). Only 3 of these 9 carbon sources accounted for most differences when comparing only SML samples (Table 2). Variables selected for SDFA of corals excluding water samples were D-galactonic acid $\gamma$-lactone (A3), Tween 80 (D1), and glucose-1phosphate (G2).

The primary differences among microbial communities living in association with corals were between healthy and diseased coral colonies. Communities living on the healthy areas of diseased colonies and diseased areas of colonies were very similar (Table 2, Fig. 2). Similar results were obtained with the samples collected from Pickles 2002, although these analyses were performed after only $72 \mathrm{~h}$ of incubation (Fig. 3a).

Analysis from Molasses 2002 (Fig. 3b) showed separation of samples extracted from the healthy and dis-

Table 1. SAS output of the linear discriminant function of the stepwise discriminant analysis of Pickles reef in 2003, including water samples. D: diseased areas of infected sea fan; H: healthy sea fans; W: water; h: healthy area of infected sea fan. See 'Results' for definition of carbon sources

\begin{tabular}{|lrrrr|}
\hline $\begin{array}{c}\text { Carbon } \\
\text { source }\end{array}$ & $\mathrm{D}$ & $\mathrm{H}$ & $\mathrm{W}$ & $\mathrm{h}$ \\
\hline Constant & -18.67793 & -11.88685 & -629.67009 & -13.30127 \\
A2 & 25.01239 & -19.11228 & 53.23436 & 12.74577 \\
C2 & -12.83160 & 3.63435 & -152.49584 & -9.27171 \\
D1 & 5.23313 & -3.07169 & 15.01539 & 4.17462 \\
E4 & -7.43741 & 3.13852 & 21.58145 & -6.94416 \\
F1 & 4.92035 & -1.10301 & 20.29187 & 3.55649 \\
G2 & -4.55609 & 2.71348 & -19.51514 & -3.11718 \\
G3 & -21.99153 & 16.21195 & -214.27812 & -5.01295 \\
H1 & 41.34666 & -12.95661 & 722.02604 & 16.89343 \\
H3 & 556.09556 & -258.02149 & 5723 & 291.46736 \\
\hline
\end{tabular}


Table 2. SAS output of the linear discriminant function of the stepwise discriminant analysis of Pickles reef in 2003, not including water samples. D: diseased areas of infected sea fan; $H$ : healthy sea fans; h: healthy area of infected sea fan. See 'Results' for definition of carbon sources

\begin{tabular}{|lrrr|}
\hline $\begin{array}{l}\text { Carbon } \\
\text { source }\end{array}$ & $\mathrm{D}$ & \multicolumn{1}{c|}{$\mathrm{H}$} & \multicolumn{1}{c|}{$\mathrm{h}$} \\
\hline Constant & -2.31859 & -7.69102 & -1.50205 \\
A3 & -40.98178 & 178.11382 & -40.09312 \\
D1 & 1.59074 & -2.36467 & 1.43327 \\
G2 & -0.39361 & 1.30064 & -0.40916 \\
\hline
\end{tabular}

eased parts of diseased colonies, but not as much as the separation from healthy colonies. Metabolic profiles from healthy colonies did not seem to be stable in space and time (Figs. 4 \& 5). The microbial activity from colonies with signs of aspergillosis (on both diseased and healthy areas of tissue) from different reefs (Fig. 4) and different years (Fig. 5) was more similar than a parallel comparison made on healthy colonies.

\section{DISCUSSION}

The composition of culturable microorganisms varies between coral mucus and seawater, sometimes with a 100 -fold increase in bacterial population in coral mucus compared to surrounding seawater (Ritchie \& Smith 1995a,b, Wild et al. 2004a,b). Qualitative and quantitative differences in the potential use of specific carbon substrates between seawater and SML communities were also found. These differences in functional diversity and the greater potential of SML microbiota

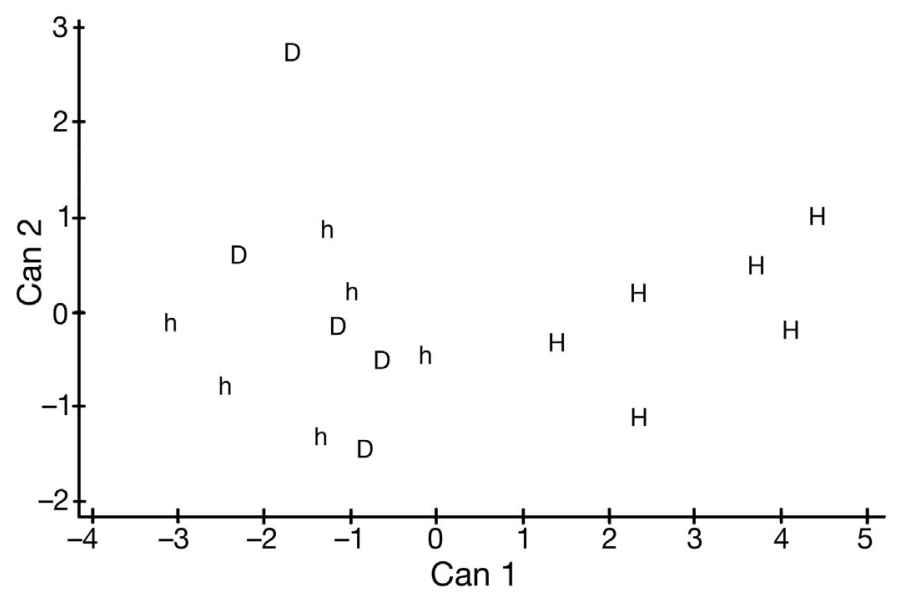

Fig. 2. Stepwise canonical analysis of the area under the curve for samples from Pickles reef (2003) after $108 \mathrm{~h}$ of incubation. H: healthy sea fans; h: healthy area of infected sea fan; D: diseased areas of infected sea fan
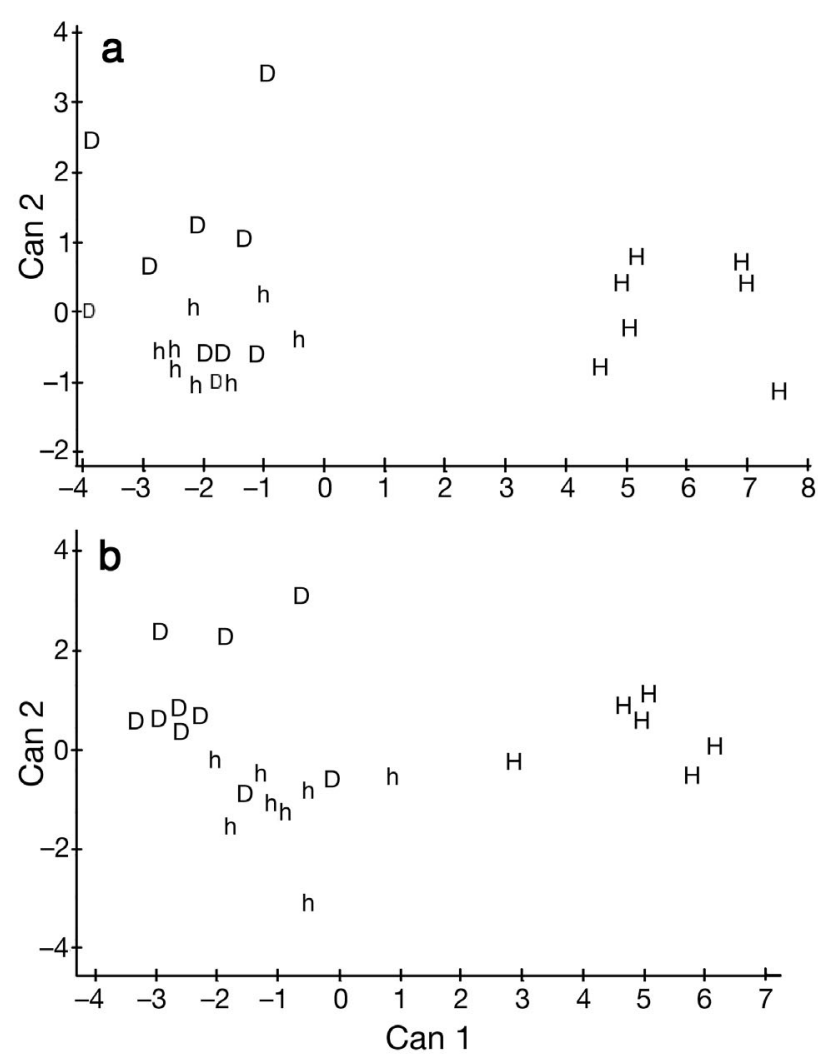

Fig. 3. Stepwise canonical analysis of the area under the curve for samples from (a) Pickles reef and (b) Molasses reef (2002) after $72 \mathrm{~h}$ of incubation. Water samples not included. $\mathrm{H}$ : healthy sea fans; h: healthy area of infected sea fan; D: diseased areas of infected sea fan

to utilize carbon sources have profound implications on the carbon cycle and productivity of coral reefs.

Differences in the AWCD of diverse samples (Fig. 1) could be due to variations in the concentration of the inoculum used (Garland \& Mills 1991, PrestonMafham et al. 2002) resulting from inconsistencies during sample collection. However, during this study, differences between samples were found to be smaller than from each sampling source. Therefore, differences were likely due to actual changes in the SML microbial communities of healthy corals over time.

Further evidence for variations in metabolic profiles from healthy corals was found when comparing functional diversity from different samples (different years and different reefs). Ritchie \& Smith (1995b) and Rohwer et al. (2001) suggested that the association between corals and bacteria living in the SML is species-specific. In other words, corals have a distinctive, species-specific community of bacteria. Results of the present study found fewer metabolic differences when comparing bacterial communities on different (disease-affected and apparently unaffected) parts of 

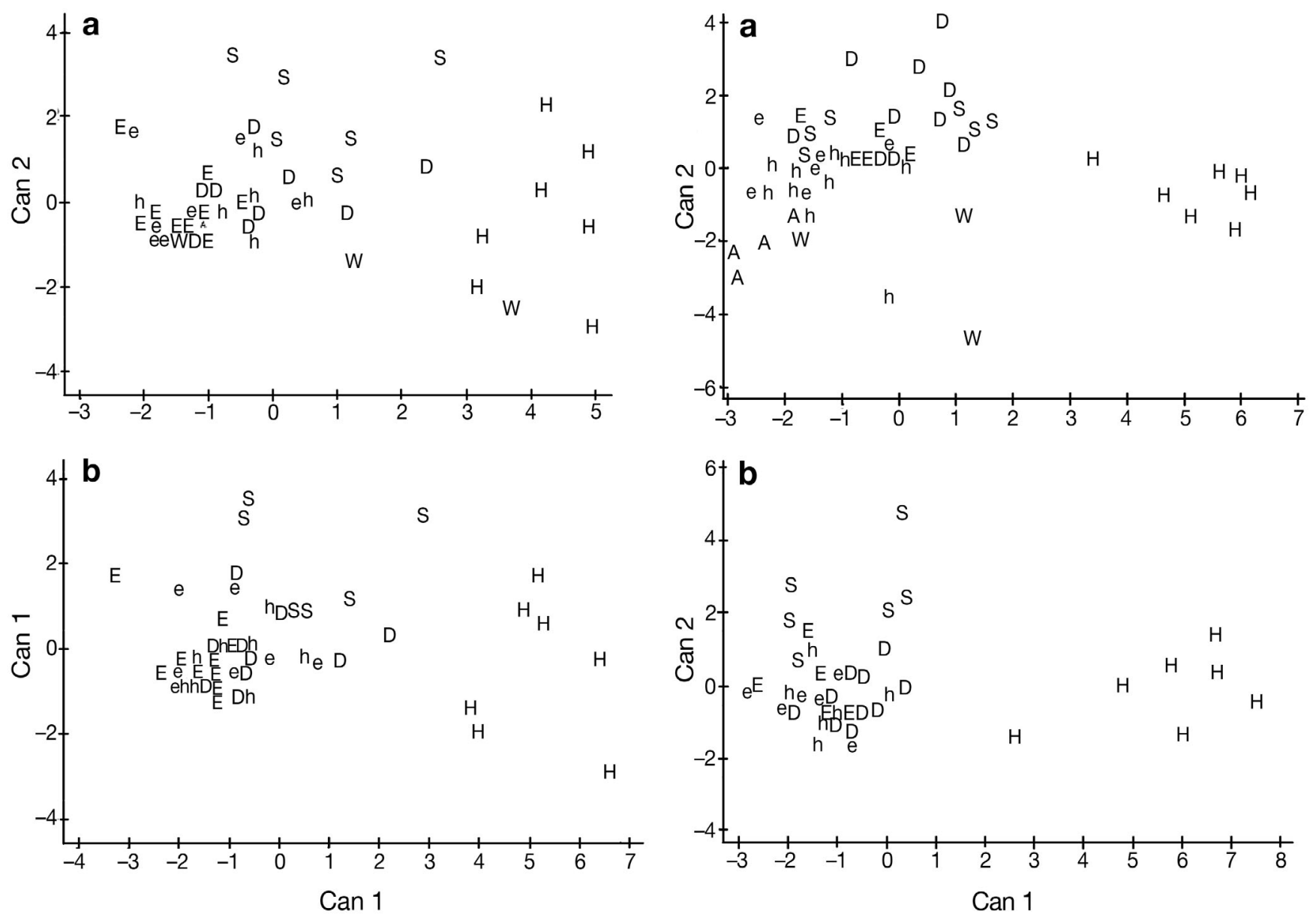

Fig. 4. Stepwise canonical analysis of the area under the curve for samples from Pickles and Molasses reefs (2002) after $72 \mathrm{~h}$ of incubation (a) including and (b) not including water samples. Pickles - W: water; H: healthy sea fans; h: healthy area of infected sea fan; D: diseased areas of infected sea fan. Molasses - A: water; S: healthy sea fans; e: healthy area of infected sea fan; E: diseased areas of infected sea fan

diseased colonies than when comparing communities on healthy seafan colonies.

Results indicated qualitative variations in space and time in the bacterial community. Microbial activity may change in response to changes in environmental conditions, including water temperature, nutrients, sedimentation, and the chemical composition of coral mucus. The fact that samples from diseased seafans (diseased and healthy parts) were more similar than healthy samples is very significant. This shows that the microbial community of the entire colony of Gorgonia ventalina is affected by the infection, and not only the portion with the visible active infection. Microbial communities living in the SML depend on the exudates produced by the coral to live (Ducklow \& Mitchell 1979a,b); therefore, changes in communities suggest

Fig. 5 Stepwise canonical analysis of the area under the curve for samples from Pickles $(2002,2003)$ after $72 \mathrm{~h}$ of incubation (a) including and (b) not including water samples. $2002-W$ : water; H: healthy sea fans; h: healthy area of infected sea fan; D: diseased areas of infected sea fan. 2003A: water; S: healthy sea fans; e: healthy area of infected sea fan; E: diseased areas of infected sea fan

changes in the exudates produced by the corals. These changes might be due to alterations in metabolism resulting from the disease. This aspect has not been investigated to date.

Kim et al. (2000) reported the production of antibiotics and antifungals by Gorgonia ventalina and $G$. flabellum as a response to infection by Aspergillus sydowii. This could alter the SML microbiota, making these communities more similar in diseased samples than in healthy samples. Although there is no definitive evidence that the SML microbiota plays a protective role for corals (as suggested by Rohwer et al. 2002), this study shows that the metabolic profile does change in infected corals, even in apparent healthy areas. Microbial population shifts resulted in either quantitative or qualitative changes that show differ- 
ences in their metabolic profiles. Further studies are necessary to determine if changes in the SML microbiota of healthy corals are due to changes in environmental conditions.

Acknowledgements. The authors thank the people involved in this work, especially J. R. Ward and K. L. Rypien for their help during collection and processing of samples and E. Weil for his comments on the paper. Funds were provided by NSF OCE-0326269, NOAA-CRES 0648-0384, FulbrightColciencias-DNP Scholarship 081-2000 (DLG-A), NURC/ Cosmos foundation. This is contribution 885 of INVEMAR.

\section{LITERATURE CITED}

Bossio DA, Scow KM (1995) Impact of carbon and flooding on the metabolic diversity of microbial communities in soils. Appl Environ Microbiol 61:4043-4050

Ducklow HW, Mitchell R (1979a) Composition of mucus released by coral reef coelenterates. Limnol Oceanogr 24(4):706-714

Ducklow HW, Mitchell R (1979b) Bacterial populations and adaptations in the mucus layer on living corals. Limnol Oceanogr 24(4): 715-725

Ferrier-Pages C, Gattuso JP, Cauwet G, Jaubert J, Allemand D (1998) Release of dissolved organic carbon and nitrogen by the zooxanthellate coral Galaxea fascicularis. Mar Ecol Prog Ser 172:265-274

Fritze H, Pennanen T, Vanhala P (1997) Impact of fertilizers on the humus layer microbial community of scots pine stands growing along a gradient of heavy metal pollution. In: Insam H, Rangger A (eds) Microbial communities. Functional versus structural approaches. Springer-Verlag, Berlin p 68-83

Garland JL, Mills AL (1991) Classification and characterization of heterotrophic microbial communities on the basis of patterns of community-level sole-carbon-source utilization. Appl Environ Microbiol 57(8):2351-2359

Gil-Agudelo DL, Smith GW, Garzón-Ferreira J, Weil E, Petersen D (2004) Dark spots disease and yellow band disease, two poorly known coral diseases with high incidence in Caribbean reefs. In: Rosenberg E (ed) Coral health and diseases. Springer-Verlag, Berlin, p 337-349

Guckert JB, Carr GJ, Johnson TD, Hamm BG, Davidson DH, Kamagai Y (1996) Community analysis by Biolog: curve integration for statistical analysis of activated sludge microbial habitats. J Microbiol Methods 27:183-197

Haack SK, Garchow H, Klug MJ, Forney LJ (1996) Analysis of the factors affecting the accuracy, reproducibility, and interpretation of microbial community carbon source utilization patterns. Appl Environ Microbiol 61:1458-1468

Hackett CA, Griffiths BS (1997) Statistical analysis of the time-course of Biolog substrate utilization. J Microbiol Methods 30:63-69

Jackson DA (1993) Stopping rules in principal component analysis: a comparison of heuristical and statistical approaches. Ecology 74(8):2204-2214

Jindal A, Ritchie KB, Hayes RL, Goreau TJ, Smith GW (1996) Bacterial ecology of selected corals following the south central pacific bleaching event. Proc Assoc Mar Labs Caribb 27:26-32

Kim K, Harvell CD, Kim PD, Smith GW, Merkel SM (2000)
Fungal disease resistance of Caribbean sea fan corals (Gorgonia spp.). Mar Biol 136:259-267

Matsui K, Jun MS, Ueki M, Kawabata Z (2001) Functional succession of bacterioplankton on the basis of carbon source utilization ability by BIOLOG plates. Ecol Res 16:905-912

Meikle P, Richards GN, Yellowlees D (1988) Structural investigations on the mucus from six species of coral. Mar Biol 99:187-193

Palojärvi A, Sharma S, Rangger A, von Lützow M, Insam H (1997) Comparison of Biolog and phospholipid fatty acid patterns to detect changes in microbial community. In: Insam H, Rangger A (eds) Microbial communities. Functional versus structural approaches. Springer-Verlag, Berlin, p 37-48

Patterson KL, Porter JW, Ritchie KB, Polson SW, Mueller E, Peters EC, Santavy DL, Smith GW (2002) The etiology of white pox, a lethal disease of the Caribbean elkhorn coral Acropora palmata. Proc Natl Acad Sci USA 99:8725-8730

Preston-Mafham J, Boddy L, Randerson PF (2002) Analysis of microbial community functional diversity using solecarbon-source utilisation profiles - a critique. FEMS Microbiol Ecol 42:1-14

Ritchie KB, Smith GW (1995a) Preferential carbon utilization by surface bacterial communities from water mass, normal, and white-band diseased Acropora cervicornis. Mol Mar Biol Biotechnol 4(4):345-352

Ritchie KB, Smith GW (1995b) Carbon-source utilization of coral-associated marine heterotrophs. J Mar Biotechnol 3: 107-109

Ritchie KB, Smith GW (2004) Microbial communities of coral surface mucopolysaccharide layers. In: Rosenberg E, Loya Y (eds) Coral health and disease. Springer-Verlag, Berlin, p 259-264

Ritchie KB, Dennis JH, McGrath T, Smith GW (1994) Bacteria associated with bleached and nonbleached areas of Montastrea annularis. Proc Symp Nat Hist Bahamas 5:75-80

Ritchie KB, Holley RA, McGrath T, Smith GW (1996) INTlinked dehydrogenase activity in the surface mucopolysaccharidae layers of Bahamian scleractinian corals. Proc Symp Nat Hist Bahamas 6:18-27

Rohwer F, Breitbart M, Jara J, Azam F, Knowlton N (2001) Diversity of bacteria associated with the Caribbean coral Montastraea franksi. Coral Reefs 20:85-91

Rohwer F, Seguritan V, Azam F, Knowlton N (2002) Diversity and distribution of coral-associated bacteria. Mar Ecol Prog Ser 243:1-10

Sinsabaugh RL, Foreman CM (2001) Activity profiles of bacterioplankton in a eutrophic river. Freshw Biol 46: 1239-1249

Wild C, Huettel M, Klueter A, Kremb SG, Rasheed MYM, Jørgensen BB (2004a) Coral mucus functions as an energy carrier and particle trap in the reef ecosystem. Nature 428:66-70

Wild C, Rasheed M, Werner U, Franke U, Johnstone R, Huettel M (2004b) Degradation and mineralization of coral mucus in reef environments. Mar Ecol Prog Ser 267: 159-171

Winding A (1994) Fingerprinting bacterial soil communities using Biolog microtitre plates. In: Ritz K, Dighton J, Giller KE (eds) Beyond the biomass: compositional and functional analysis of soil microbial communities. WileySayce, Chichester, p 85-94

Zak JC, Willig MR, Moorhead DL, Wildman HG (1994) Functional diversity of microbial communities: a quantitative approach. Soil Biol Biochem 26:1101-1108 